\title{
Impact of Two Hydrophilic Acrylic-Based Polymers on the Physical Properties of Three Substrates and the Growth of Petunia xhybrida 'Brilliant Pink'
}

\author{
Philippe Jobin \\ Centre de recherche en horticulture, Pavillon Envirotron, Université Laval, Sainte-Foy, Québec, \\ Canada, G1K 7 P4 \\ Jean Caron ${ }^{1}$ \\ Centre de recherche en horticulture, Facultédes Sciences de l'Agriculture et de l'Alimentation, Université \\ Laval, Sainte-Foy, Québec, Canada, G1K 7P4
}

Pierre-Yves Bernier

Natural Resources Canada, Canadian Forest Service, Laurentian Forestry Centre, 1055 du P.E.P.S., P.O. Box 3800, Sainte-Foy, Québec. Canada, G1V 4C7

Blanche Dansereau ${ }^{2}$

Centre de recherche en horticulture, Facultédes Sciences de l'Agriculture et de l'Alimentation, Université Laval, Sainte-Foy, Québec, Canada, G1K 7P4

ADDITIONAL INDEX WORDS. water availability, water retention, hydraulic conductivity

\begin{abstract}
AвSTRACT. Hydrophilic polymers or hydrogels have shown potential to increase water retention of media and to reduce irrigation frequency. This property would be particularly useful in the production of fast growing species in which large amounts of water are needed. This study evaluated the effect of two acrylic-based hydrogels on water desorption curve and hydraulic conductivity of substrates and on plant growth. The duration of their effects was also investigated. Rooted cuttings of Surfinia (Petunia $\times$ hybrida 'Brilliant Pink') were transplanted into $30-\mathrm{cm}$ pots containing one of three different substrates amended with one of two types of hydrogels, a commercial acrylic polymer, and a commercial acrylic-acrylamide copolymer, and grown for 9 weeks under well watered conditions and then imposed with a drought. Results indicated that both polymer types gave similar results. The substrates' physical properties (air-filled porosity, available water) at potting time were significantly affected by hydrogel addition, but differences vanished within 9 weeks of growth. Hydrogels had no significant effect on the point at which plant wilted and on the substrate's unsaturated hydraulic conductivity. Shoot dry weight was affected by substrate and hydrogel and was positively correlated to water content between container capacity and $-10 \mathrm{kPa}$ of water potential, or between container capacity and the soil water potential at plant turgor loss.
\end{abstract}

The irrigation needs of container-potted plants and hanging baskets are a major concern in plant production and maintenance. An important strategy for reducing these needs is to improve the amount of available water for plant growth in the medium. Once potted and irrigated, substrates drain to quasi-equilibrium that tends to a higher water potential than in agricultural soils, the phenomenon being linked to container height (White, 1965). Growing media have to be much coarser than natural soils to maintain adequate substrate aeration, but the improvement in air-filled porosity is often made at the expense of the amount of water available to the plant. The growing media industry therefore seeks and uses components that provide a maximum amount of available water. Sphagnum peat is one of these components because of the presence of remnant internal cell structures, the hydrocysts, which internally store some water. Sphagnum peat also stores water between fibers (Rivière, 1992). Moreover, some available water may be stored on the external vermiculite structure and between composted fragments. Therefore, available water is expected to vary with substrate composition.

Received for publication 19 Mar. 2003. Accepted for publication 13 Nov. 2003. The authors acknowledge the financial contribution of Hydro-Agri and the Conseil des Recherches en Pêches et Agroalimentaire du Québec (CORPAQ).

'Département des sols et de génie agroalimentaire.

${ }^{2}$ Département de phytologie.
Hydrogels are sometimes used in addition to natural organic and inorganic fragments to increase available water in substrates of greenhouse crop production. Hydrogels are grouped into three main classes (James and Richard, 1986): 1) natural polymers, usually composed of starch, 2) synthetic polymers made from acrylic acid (polyacrylate, polyacrylamide) or from polyvinylalcohol, and 3) a mixture of both types (intermediate copolymers). Hydrophilic polymers (HP) can store several hundred times their own dry weight of water (Orzolek, 1993) and can potentially increase available water when incorporated into a medium (Terry and Nelson, 1986). Dehgan et al. (1994) have shown that HP addition led to reduced irrigation frequencies without affecting the growth of Photinia $\times$ fraseri. Taylor and Halfacre (1986), Flannery and Busscher (1982), and Wang and Boogher (1987) also reported reduced water needs when growing ornamental plants. Finally, Blodgett et al. (1995) and Wang (1989) observed a delayed plant wilting with HP product.

The amount of available water in substrates is established from the water release curve and calculated as the difference between container capacity (the amount of water stored after saturation and drainage of the pot) and a threshold value (Fig. 1). The value of $-10 \mathrm{kPa}$ is often used as the threshold since yield decreases can be observed in species that show some loss of turgor at potentials at and below this value (de Boodt and Verdonck, 1972). However, any threshold value must be considered as only a rough estimate 


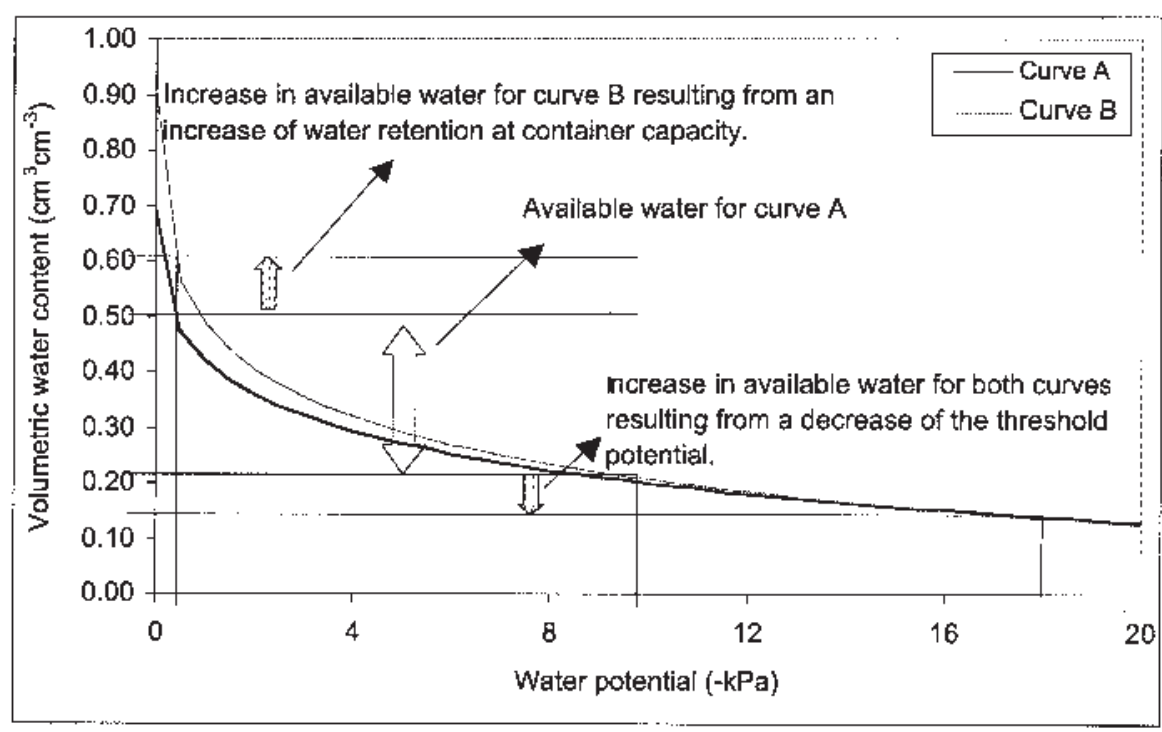

ity. This improvement is expected to vary with substrate composition, as the proportion of fine particles affects the properties of the soil root interface (Örlander and Due, 1986).

HP could also alter the amount of interfacial surface between the soil and the root. The extent of this surface is critical to root water uptake (Glinski and Lipiec, 1990). The rapid depletion of the water volume at the interface (Kozinka, 1992) creates air pockets that decrease the contact surface between the soil and the roots. Shrinkage of drying roots also results in a loss of interfacial surfaces (Kozinka, 1992). Örlander and Due (1986) have shown that peat substrates offer a particularly low interfacial contact relative to a mineral soil-peat mix. Root exudates are capable of partially filling the soil-root gap (Greenland, 1979) and HP could possibly play a similar role. The addition of HP could lower the threshold value for

Fig. 1. Water desorption curves of a given substrate along with available water evaluated with different thresholds (arrows).

of the soil potential at which the water stress begins since water stress results from several dynamic processes in the rhizosphere (Caron et al., 1998). Indeed, the water stored by capillary action between particles and within hydrocysts in peat substrates must move sufficiently fast to the root interface to meet plant needs. Flux toward the root follows Darcy-Buckingham's equation in one dimension and under steady-state conditions:

$Q / A=-K(\psi) d H / d z$

where $\mathrm{Q}$ is the flux of water towards the root surface, $\mathrm{A}$ is the effective area, $K(\psi)$ is the soil unsaturated hydraulic conductivity, $\mathrm{H}$ is the total water potential, $\mathrm{z}$ is the distance, and $\mathrm{dH} / \mathrm{dz}$ is the hydraulic gradient between the two locations. Unsaturated hydraulic conductivity has a large influence on the flux between two points and varies strongly with substrate potential. Another factor is the size of the effective interfacial section, which will affect the efficient root surface toward which water can move. Finally, the last factor is the potential of water within the root that is maintained through evaporative demand at a level that permits movement from the soil into the plant transpiration stream. This flux toward the root may be reduced if solute accumulation at the root external boundary decreases the osmotic potential of the surrounding soil and causes substantial plant water deficit.

Rivière et al. (1996) observed that HP can increase the amount of available water between -1 and $-10 \mathrm{kPa}$ measured from the water desorption curves of coarse substrates. However, HP may affect other factors controlling water availability in the rhizosphere. For example, the fibrous nature of peat relative to that of mineral soils leads to poor contact between particles (Örlander and Due, 1986). Water uptake during transpiration rapidly depletes the water surrounding the roots, generating an important drop in unsaturated hydraulic conductivity, and a corresponding drop in water potential at the soil root interface. HP could improve that contact between particles and hence increase the unsaturated hydraulic conductiv-

Table 1. Particle size distribution $(\mathrm{g} / \mathrm{g})$ of the different substrates. available water through its impact on unsaturated conductivity and on the soil-root contact (Fig. 1), but these factors have so far received little attention.

Finally, physical properties of substrates evolve in time (Allaire-Leung et al., 1999; De Rouin, 1988) in ways that could alter $\mathrm{HP}$ effects. Pronounced interactions between fertilizers and HP, particularly $\mathrm{Ca}^{2+}, \mathrm{Fe}^{3+}$, and $\mathrm{Mg}^{2+}$, may also seriously reduce $\mathrm{HP}$ polymereffects (Bowman and Evans, 1991). Both phenomena could quickly inactivate HP in hanging baskets, well before they are sold and any outdoor stress is imposed on the transpiring plant. It is then critical to follow the evolution of substrate-HP interactions over time. The objectives of this study were therefore to determine if the use of HP addition significantly modified the growth of Surfinia in hanging baskets and if the effect was substrate and/or polymer dependent. An attempt was made to identify the mechanisms by which substrates and HPadditives modified plant growth, by evaluating the chemical ( $\mathrm{pH}, \mathrm{EC}$ macro and micro elements) and physical (available water and unsaturated hydraulic conductivity) substrate properties. The duration of the effect was also evaluated.

\section{Materials and Methods}

\section{Plant growth and analysis}

Plant GrowTh. The experiment was carried out in a Nordic-type double polyethylene greenhouse with forced air ventilation (Les Industries Harnois, St-Thomas-de-Joliette, Québec) at Université Laval (lat. $46^{\circ} 47^{\prime}$, long. $71^{\circ} 23^{\prime}$ ) during the Spring-Summer of 1998. The experiment was initiated by transplanting rooted cuttings of Surfinia (Petunia $\times$ hybrida 'brilliant Pink") into $30-\mathrm{cm}$ (8-liter vol.) hanging baskets (Kord Products Ltd, Ontario). We used three cuttings in each basket. The baskets contained one of the three following substrates: the first, PRO-MIX ' $\mathrm{BX}$ ' (S:P: $\mathrm{V})$, is a commercial substrate consisting of $75 \%$ sphagnum (S) peatmoss (H3 to $\mathrm{H} 4$ on the van Post scale), $12.5 \%$ perlite $(\mathrm{P})$, and $12.5 \%$ vermiculite $(\mathrm{V})$ on a volume basis (Les Tourbières

\begin{tabular}{lccccccc}
\hline & \multicolumn{5}{c}{ Particle size } \\
\cline { 2 - 7 } Substrate & $2 \mathrm{~mm}$ & $1 \mathrm{~mm}$ & $500 \mu \mathrm{m}$ & $250 \mu \mathrm{m}$ & $75 \mu \mathrm{m}$ & $45 \mu \mathrm{m}$ & $<45 \mu \mathrm{m}$ \\
\hline SPV & 0.10 & 0.20 & 0.26 & 0.20 & 0.16 & 0.03 & 0.01 \\
SPVC & 0.13 & 0.19 & 0.29 & 0.24 & 0.10 & 0.00 \\
CPV & 0.18 & 0.25 & 0.24 & 0.21 & 0.08 & 0.01 \\
\hline
\end{tabular}


Premier, Rivière-du-Loup, Québec). The second substrate (S:P: $\mathrm{V}: \mathrm{C}$ ) contained $80 \%$ PRO-MIX 'BX' and $20 \%$ compost (C) (Les Composts du Québec, St-Henri-de-Lévis, Québec) on a volume basis. The third substrate $(\mathrm{C}: \mathrm{P}: \mathrm{V})$ was composed of three equal volumes of compost, perlite, and vermiculite. The particle size distribution, as measured by drying and sieving, is given in Table 1. Each substrate was amended with one of the following hydroretention agents (HP). The first type, Aqua-Mend (A) (Hydration Technology Corp., Santa Monica, CA), is a potassium reticulated acrylic polymer available in granular form. The second type, Soil Moist (M) (JRM Chemical Inc. Ohio), is a synthetic acrylic and acrylamide copolymer available in powder form. Each hydroretention agent was manually incorporated at levels of $3 \mathrm{~g} \cdot \mathrm{L}^{-1}(\mathrm{~A})$ and $2 \mathrm{~g} \cdot \mathrm{L}^{-1}(\mathrm{M})$ of substrate.

Plants were given a constant liquid feed manually using a soluble fertilizer Kristalon 19-6-20 (Hydro Agri Rotterdam B.V., The Netherlands), providing 250 ppm of N, 79 of P, 264 of K, 24 of $\mathrm{Mg}, 0.92$ of Fe, 0.53 of $\mathrm{Mn}, 0.33$ of B, 1.11 of Mo, 0.33 of $\mathrm{Zn}$, and 0.13 of $\mathrm{Co}$ at each watering. Temperature in the greenhouse was maintained at $18 \pm 3{ }^{\circ} \mathrm{C} / 16 \pm 1{ }^{\circ} \mathrm{C}$ day/night throughout the experiment. Photoperiod was natural as no artificial lighting was used. Surfinia plants were pinched on 9 and 22 Apr. to improve secondary branching.

Monitoring of soil water content was performed through time domain reflectometry (Topp et al., 1980). Measurements of the dielectric constant $(\mathrm{Ka})$ of each substrate were made daily with a Tektronix 1502-C (Tektronix, Beaverton, Ore.) and a three-rod, $13 \mathrm{~cm}$ probe. The dielectric constant (Ka) was converted to the volumetric soil water content $(\theta)$ using the equation of Paquet et al. (1993). However, for Ka values greater than 55, we used the following equation which extrapolates the equation of Paquet et al. (1993) from $\mathrm{ka}=55$ to the theoretical value of $100 \mathrm{~cm}^{3} \cdot \mathrm{cm}^{-3}$ at $\mathrm{Ka}=81$ :

$\theta=0.0042 \mathrm{Ka}+0.6635$

One measurement was taken daily within each experimental unit (see below). Irrigation to container capacity $(-0.6 \mathrm{kPa})$ was applied when substrate water potential reached $-5 \mathrm{kPa}$ (de Boodt and Verdonck, 1972). Very little drainage occurred following watering, so, periodically, salts were leached by adding a liter of water after watering to maintain substrate salinity below $3 \mathrm{dS} \cdot \mathrm{m}^{-1}$.

Plant analysis. At the end of the experiment, all shoots were harvested and dried at $70^{\circ} \mathrm{C}$ to determine dry mass. Mineral analysis of Surfinia top biomass was also carried out. Digestions were done according to the nitric and perchloric acid method (Richards, 1993). Total nitrogen was obtained by the macro-Kjeldahl method(Helrich, 1990); phosphate was analyzed by the vanadomolybdate of ammonium method; calcium, magnesium, and iron were determined by atomic absorption spectrophotometer analysis and potassium by atomic emission spectrophotometer (Ure, 1991).

\section{Soil and plant measurements}

WATER DESORPTION CURVES. We obtained the initial physical properties of each substrate (pore space, water-holding capacity) through substrate water desorption curves obtained using European standards (European Committee for Standardization, method EN 13040; Brussels, Belgium). A second water desorption curve was obtained 9 weeks later from in situ measurements of water content and substrate potential (Paquet et al., 1993). Before shoot harvesting, at the end of the experiment, the 81 containers were saturated and left to dry. During the dry-down of the substrates, we followed the evolution of plant water content, soil volumetric water content and soil water potential. Soil volumetric water con- tent was measured as above with a Tektronix 1502-C (Tektronix, Beaverton, Ore.) and a three-rod $13-\mathrm{cm}$ probe. Bulk soil water potential values were measured using tensiometers made with 5.0 $\times 2.4-\mathrm{cm}$ porous cups mounted on 20-cm PVC tubes. A tensiometer was placed vertically in each hanging basket with the porous cup at mid-substrate height position $(6 \mathrm{~cm})$. Potentials were measured through a pressure transducer (Tensimeter, Soil Measurement Systems, Tucson, Ariz.).

Plant water content. We measured fresh, saturated and dry mass on two terminal stems per basket collected daily during the dry-down of the substrates and the plants. Saturation was obtained by holding the stems in water, in darkness for $12 \mathrm{~h}$. Dry mass was measured after drying for $48 \mathrm{~h}$ in an oven at $70^{\circ} \mathrm{C}$. Relative water content (RWC) was calculated as

$R W C=($ fresh mass - dry mass $) /$

(saturated mass - dry mass)

Calculation OF WATER AVAILABILITY USING DifFERENT CRITERIA. Easily available water (EAW) and available water (AW) were computed as water retained by the substrate between container capacity $(-0.6 \mathrm{kPa})$ and either -5 or $-10 \mathrm{kPa}$ (de Boodt and Verdonck, 1972). A plant-based calculation of available water was also made in two different ways: the plant easily available water (PEAW) and the plant available water (PAW). We obtained PEAW from the plant RWC curves as a function of bulk soil water potential (Fig. 2). The threshold potential at which the plant RWC starts dropping was established from these curves by fitting segmented regression lines to data of the plant RWC-bulk soil water potential curves. The threshold was determined as the intersect value for the two fitted segmented curves (Hudson, 1966; Caron et al., 1998).
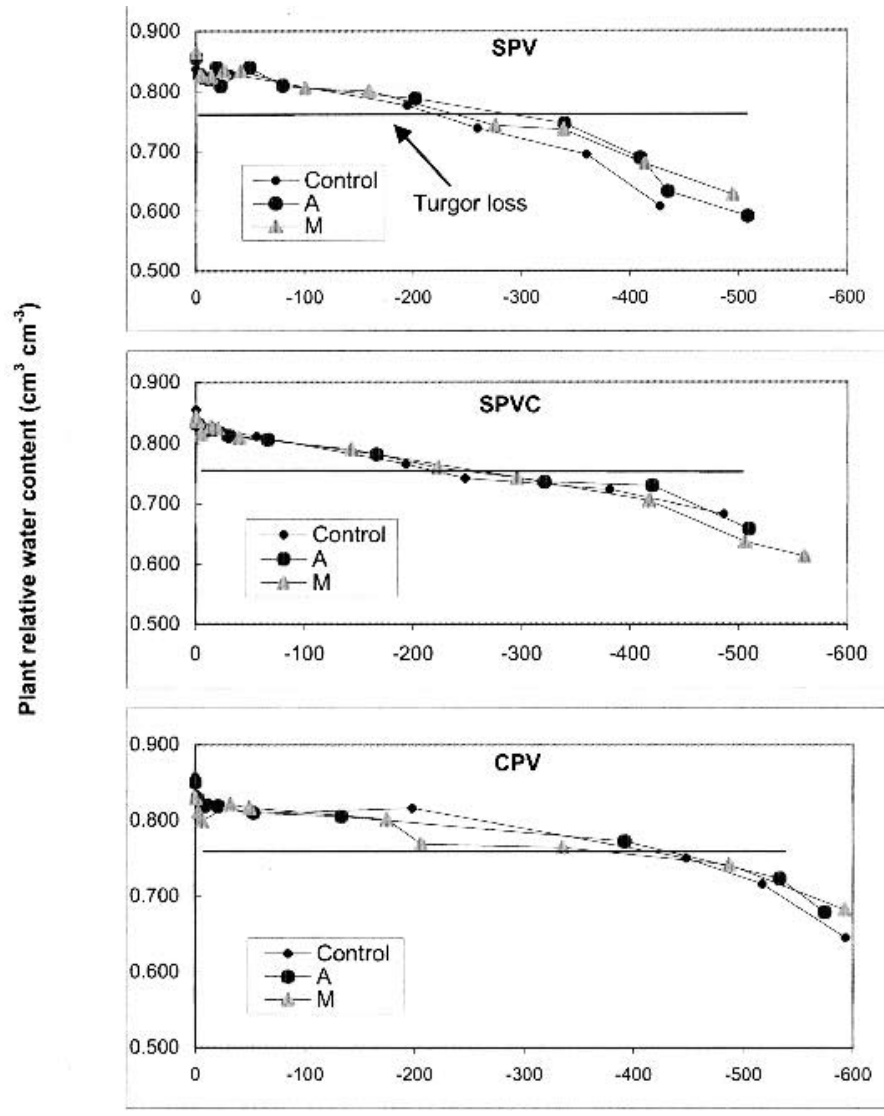

Water potential $(\mathbf{k P a})$

Fig. 2. Relative plant water content as a function of substrate water potential in amended and nonamended substrates. 
The PEAW was computed as the difference between the substrate water content at container capacity (i.e. $-0.6 \mathrm{kPa}$ ) and that at the threshold value. Both values of water content were obtained from the function of Milks et al. (1989) fitted to the 9 water release (or desorption ) curves:

$\left.\theta(\Psi)=\theta_{r}+\left(\theta_{s}-\theta_{r}\right) /[1+\beta \Psi)^{n}\right]^{m}$

where $\theta$ is the substrate water content at potential $\Psi, \theta_{r}$ is the residual water content corresponding to the horizontal asymptote of the curve, $\theta_{s}$ is the water content at saturation, and $\beta, n$, and $m$ are empirical constants.

PAW was calculated using the value of $\Psi$ at which Surfinia lost turgor $\left(\Psi_{T L P}\right)$. Values of $\Psi_{T L P}$ were obtained from pressure-volume (PV) curves using the composite PV curve method of Parker and Colombo (1995). Measurements were done using a pressure chamber (model 3000; Soil Moisture Equipment Corp., Santa Barbara, Calif.). The PV curve has been performed on Surfinia terminal stems collected regularly on the same plant during the dry-down of the containers. The PAW was computed as the difference between the substrate water content between container capacity and $\Psi_{T L P}$.

ESTIMATION OF THE SUBSTRATE UNSATURATED HYDRAULIC CONDUCTIVITY. We obtained the unsaturated hydraulic conductivity $(K(\psi))$ of the various substrates using the instantaneous profile method (Hillel et al., 1972). The samples were saturated and allowed to drain on a tension table at $-10 \mathrm{kPa}$ potential (Paquet et al., 1993). Periodically, within each sample, we measured simultaneously the hydraulic gradient between the top and bottom of the substrate using a pair of tensiometers, and the substrate volumetric water content using a TDR. Calculations were made according to the theoretical approach of Hillel et al. (1972). The relationship between the hydraulic conductivity and water potential was described by the Gardner equation (Stephens, 1996):

$K(\psi)=K_{S} e^{(\alpha \psi)}$

where $K_{S}$ is the saturated hydraulic conductivity and $\alpha$ is an empirically fitted parameter.
SoIL CHEMICAL ANALYSIS. Water was extracted from substrates according to the methodology approved by the Conseil des productions végétales du Québec (CPVQ, 1988), using three replications per treatment. The following elements were quantified: nitrogen $\left(\mathrm{NO}_{2}\right.$ and $\left.\mathrm{NO}_{3}\right)$, phosphates, chlorides and sulfates, separated by gas-liquid chromatography (Dionex Corporation, Sunnyvale, Calif.), and potassium, calcium, magnesium iron and sodium separated by atomic absorption/emission spectrophotometer (Perkin-Elmer Product, Norwalk, Conn.). Water $\mathrm{pH}$ and electrical conductivity were also measured (CPVQ, 1988).

\section{Experimental design}

The treatment structure was a complete 3 (substrate) $\times 3(\mathrm{HP}$ effects) factorial. The experimental design was a completely randomized block and included 9 treatments distributed in three blocks for a total of 27 experimental units. Each unit contained 3 baskets, for a total of 81 baskets. Treatment effects were evaluated using an analysis of variance and a multiple comparison test (LSD 0.05) using the Statistical Analysis System (SAS Institute, Raleigh, N.C.). Statistical analyses for dry mass and physical properties after 9 weeks, but not for hydraulic conductivity, were done on the 81 baskets using an average of the three subsamples for each experimental unit. For all other variables, statistical analyses were done on 1 basket per experimental unit (27 baskets).

\section{Results and Discussion}

Plant Growth. In control (no HP addition) pots, Surfinia dry mass was highest in the SPVC substrate, followed by the SPV and the CPV substrates. Surfinia dry mass also significantly increased with both hydrogels incorporated in SPV, significantly reduced with hydrogel A addition in SPVC, and remained unchanged in CPV (Table 2), resulting in a significant substrate x polymer interaction in the ANOVA. The significant interaction term indicates that HP

Table 2. Shoot dry mass and chemical composition of plants and substrates for which differences were found after growing for 9 weeks in different substrates amended with different polymers.

\begin{tabular}{|c|c|c|c|c|c|c|c|}
\hline \multirow[b]{2}{*}{ Treatment } & \multirow{2}{*}{$\begin{array}{c}\text { Dry } \\
\text { mass } \\
(\mathrm{g})\end{array}$} & \multicolumn{2}{|c|}{ Biomass } & \multicolumn{4}{|c|}{ Substrate } \\
\hline & & $\begin{array}{l}\text { Nitrogen } \\
\left(\mathrm{mg} \cdot \mathrm{kg}^{-1}\right)\end{array}$ & $\begin{array}{c}\text { Potassium } \\
\left(\mathrm{mg} \cdot \mathrm{kg}^{-1}\right)\end{array}$ & $\begin{array}{c}\text { Potassium } \\
\left(\mathrm{mg} \cdot \mathrm{L}^{-1}\right)\end{array}$ & $\begin{array}{c}\text { Sodium } \\
\left(\mathrm{mg} \cdot \mathrm{L}^{-1}\right)\end{array}$ & $\mathrm{pH}$ & $\begin{array}{l}\text { Salinity } \\
\mathrm{dS} \cdot \mathrm{m}^{-1}\end{array}$ \\
\hline$\overline{\text { SPV:C }}$ & 167.0 & 32000 & 45725 & 91.4 & 25.8 & 5.02 & 2.48 \\
\hline SPV:A & 211.1 & 31000 & 55752 & 162.2 & 40.7 & 4.69 & 2.63 \\
\hline SPV:M & 192.0 & 32300 & 46556 & 100.4 & 75.7 & 4.57 & 3.04 \\
\hline SPVC:C & 195.1 & 27000 & 44102 & 89.0 & 68.5 & 4.62 & 3.38 \\
\hline SPVC:A & 166.4 & 26700 & 53922 & 289.3 & 76.1 & 4.70 & 3.77 \\
\hline SPVC:M & 175.7 & 28000 & 46173 & 126.0 & 106.7 & 4.30 & 3.73 \\
\hline CPV:C & 151.9 & 28000 & 52684 & 115.0 & 78.7 & 4.83 & 3.8 \\
\hline CPV:A & 155.4 & 26300 & 54335 & 536.3 & 100.3 & 5.09 & 4.38 \\
\hline CPV:M & 139.8 & 27700 & 44003 & 141.1 & 414.7 & 5.14 & 4.38 \\
\hline \multicolumn{8}{|l|}{ Mean substrate } \\
\hline SPV & 190.1 & 31800 & 49344 & 118.0 & 47.5 & 4.75 & 2.72 \\
\hline SPVC & 179.0 & 27200 & 50341 & 168.1 & 83.8 & 4.54 & 3.62 \\
\hline CPV & 149.0 & 27300 & 48065 & 264.1 & 197.5 & 5.02 & 4.18 \\
\hline \multicolumn{8}{|l|}{ Mean polymer } \\
\hline Control & 171.3 & 29000 & 47503 & 98.5 & 57.7 & 4.82 & 3.22 \\
\hline A & 177.6 & 28000 & 54670 & 329.3 & 72.4 & 4.83 & 3.59 \\
\hline M & 169.2 & 29300 & 45577 & 122.5 & 199.0 & 4.66 & 3.71 \\
\hline LSD $(0.05)$ & 23.72 & 1060 & 4214.1 & 157.23 & 141.56 & 0.2667 & 0.544 \\
\hline \multicolumn{8}{|l|}{ Probability } \\
\hline Substrate & 0.0003 & 0.0001 & 0.5312 & 0.0113 & 0.0034 & 0.0001 & 0.0010 \\
\hline Polymer & 0.3809 & 0.0431 & 0.0008 & 0.0001 & 0.0037 & 0.0737 & 0.1641 \\
\hline Substrate $\times$ polymer & 0.0112 & 0.8092 & 0.2078 & 0.0260 & 0.0178 & 0.0027 & 0.9275 \\
\hline
\end{tabular}


Table 3. Substrate physical properties at planting time and 9 weeks after addition and cultivation.

\begin{tabular}{|c|c|c|c|c|c|c|}
\hline \multirow[b]{2}{*}{ Treatment } & \multicolumn{3}{|c|}{ Planting time } & \multicolumn{3}{|c|}{ After 9 weeks } \\
\hline & $\begin{array}{l}\text { Air-filled } \\
\text { porosity } \\
\left(\mathrm{cm}^{3} \cdot \mathrm{cm}^{-3}\right)\end{array}$ & $\begin{array}{c}\text { Easily } \\
\text { available } \\
\text { water } \\
\left(\mathrm{cm}^{3} \cdot \mathrm{cm}^{-3}\right)\end{array}$ & $\begin{array}{l}\text { Available } \\
\text { water } \\
\left(\mathrm{cm}^{3} \cdot \mathrm{cm}^{-3}\right)\end{array}$ & $\begin{array}{l}\text { Air-filled } \\
\text { porosity } \\
\left(\mathrm{cm}^{3} \cdot \mathrm{cm}^{-3}\right)\end{array}$ & $\begin{array}{c}\text { Easily } \\
\text { available } \\
\text { water } \\
\left(\mathrm{cm}^{3} \cdot \mathrm{cm}^{-3}\right)\end{array}$ & $\begin{array}{c}\text { Available } \\
\text { water } \\
\left(\mathrm{cm}^{3} \cdot \mathrm{cm}^{-3}\right)\end{array}$ \\
\hline$\overline{\mathrm{SPV}: \mathrm{C}}$ & 0.26 & 0.24 & 0.34 & 0.25 & 0.23 & 0.33 \\
\hline SPV:A & 0.24 & 0.27 & 0.37 & 0.26 & 0.23 & 0.32 \\
\hline SPV:M & 0.23 & 0.27 & 0.38 & 0.23 & 0.22 & 0.32 \\
\hline SPVC:C & 0.19 & 0.25 & 0.36 & 0.26 & 0.22 & 0.30 \\
\hline SPVC :A & 0.16 & 0.27 & 0.38 & 0.27 & 0.21 & 0.29 \\
\hline SPVC:M & 0.15 & 0.26 & 0.38 & 0.22 & 0.22 & 0.30 \\
\hline $\mathrm{CPV}: \mathrm{C}$ & 0.23 & 0.15 & 0.21 & 0.28 & 0.17 & 0.23 \\
\hline CPV:A & 0.31 & 0.10 & 0.13 & 0.28 & 0.16 & 0.22 \\
\hline CPV:M & 0.25 & 0.12 & 0.17 & 0.21 & 0.16 & 0.22 \\
\hline \multicolumn{7}{|l|}{ Mean substrate } \\
\hline SPV & 0.24 & 0.26 & 0.36 & 0.24 & 0.23 & 0.32 \\
\hline SPVC & 0.17 & 0.26 & 0.37 & 0.25 & 0.21 & 0.30 \\
\hline CPV & 0.26 & 0.13 & 0.17 & 0.26 & 0.16 & 0.23 \\
\hline \multicolumn{7}{|l|}{ Mean polymer } \\
\hline $\mathrm{C}$ & 0.23 & 0.22 & 0.30 & 0.27 & 0.21 & 0.29 \\
\hline A & 0.24 & 0.21 & 0.29 & 0.27 & 0.20 & 0.28 \\
\hline M & 0.21 & 0.22 & 0.31 & 0.22 & 0.20 & 0.28 \\
\hline LSD $(0.05)$ & 0.036 & 0.022 & 0.022 & 0.028 & 0.001 & 0.015 \\
\hline \multicolumn{7}{|l|}{ Probability } \\
\hline Substrate & 0.0001 & 0.0001 & 0.0001 & 0.5285 & 0.0001 & 0.0001 \\
\hline Polymer & 0.0457 & 0.8240 & 0.2410 & 0.0040 & 0.2255 & 0.3675 \\
\hline Substrate $\times$ polymer & 0.0033 & 0.0008 & 0.0013 & 0.6714 & 0.7962 & 0.8048 \\
\hline
\end{tabular}

benefits the sphagnum substrates, but the effect is reversed when there is compost in the substrate. Adding HP to a compost: perlite: vermiculite mix had no effect at all. The ANOVA also indicated that the substrate effect was more certain than the interaction itself, suggesting that the addition of polymer in substrate has limited improvement possibilities relative to substrate composition.

WATER DESORPTION CURVES AND SOIL WATER AVAILABILITY. SUbstrate air-filled porosity $\left(\theta_{a}\right)$ evaluated immediately after hydrogel addition was modified by polymers (Table 3 ). The value of $\theta_{a}$ was lowered by hydrogel M in both SPV and SPVC substrates. However, the value of $\theta_{a}$ in substrate CPV amended with hydrogel A was greater than that of the control $\left(0.31 \mathrm{vs} 0.23 \mathrm{~cm}^{3} \cdot \mathrm{cm}^{-3}\right)$. This resulted in a significant substrates $\times$ polymer interaction. Several authors have reported significant decreases in $\theta_{a}$ following hydrogel addition (Flannery and Busscher, 1982; Fonteno and Bilderback, 1993; Heiskanen, 1995; Tripepi et al., 1991). Significant increases in $\theta_{a}$ after hydrogel addition have not been reported so far, but their aggregative action, due to their absorption properties, might be involved (Rivière et al., 1996). This property is already used in mineral soils to reduce erosion and increase water infiltration (BenHur et al., 1992; Malik and Letey, 1991; Seybold, 1994). After 9 weeks, hydrogel A had no more influence on $\theta_{a}$ (Table 3 ) while it significantly decreased with $\mathrm{M}$ in all three substrates.

Soil water availability was also modified by hydrogel addition. Water available between container capacity and $-5 \mathrm{kPa}$ (EAW) significantly increased at transplanting time in SPV, strongly reduced in CPV and remained unchanged in SPVC with both polymers (Table 3). Water available between $\theta_{c}$ and $-10 \mathrm{kPa}(\mathrm{AW})$ behaved as EAW, except for the lack of significant effect in SPV with hydrogel A. These results support those of other researchers who reported AW and/or EAW increases (Al-Harbi et al., 1999; Choudhary et al., 1995; Flannery and Busscher, 1982; Wang and Gregg, 1990), or no change (Blodgett et al., 1993; Ingram and Yeager, 1987).
The differences in substrate response to hydrogel addition could be attributed to different substrate compositions, as reported by Rivière et al. (1996).

All differences observed for EAW and AW disappeared after 9 weeks (Table 3). Cyclical wetting and drying may have caused fragmentation of the polymers (Seybold, 1994). Alternatively, the hydrogel may have undergone a biological degradation, despite a natural resistance to microflora (Mikkelsen, 1994). Finally, constant fertilization does add significant amounts of cations $\left(\mathrm{Fe}^{+3}\right.$, $\mathrm{Ca}^{+2}, \mathrm{Mg}^{+2}$ ), which is likely to provoke polymer contraction and a corresponding significant loss of efficiency (Bowman et al., 1990; Johnson, 1984).

Values of PEAW obtained by combining soil water potentials and plant RWC data (Fig. 2) were not affected by either substrates or hydrogels. Values of PEAW were ranging from 0.06 to 0.23 $\mathrm{cm}^{3} \cdot \mathrm{cm}^{-3}$ with an average of $0.16 \mathrm{~cm}^{3} \cdot \mathrm{cm}^{3}$. The drop of PEAW occurs at bulk soil potentials between -1.6 and $-8.0 \mathrm{kPa}$ with an average of $-5.3 \mathrm{kPa}$, a value close to the $-5 \mathrm{kPa}$ used for the determination of EAW in substrates. Variability among replicates was particularly high, possibly due to the sampling of different stems from time to time.

During soil dry-down, loss of turgor in the drying Surfinia was observed to occur around a bulk soil water potential of -25 to $-47 \mathrm{kPa}$ depending on the substrates (Table 4). Hydrogels did not significantly increase the point at which wilting occurred, nor did they change PAW. This finding supports Lamont and O'Connell's (1987) observations that indicated no impact of hydrogels on the wilting of Petunia $\times$ hybrida 'Blue Pettycoat' and Tagetes erecta 'Queen Sophie', but contrast with other results that show delayed wilting with hydrogel additions (Blodgett et al., 1995; Gehring and Lewis, 1980, Rigas et al., 1999; Wang, 1989).

Substrates with the highestPAW were also those that experienced wilting at the highest potential. The occurrence of wilting at those 
Table 4. Water availability obtained from plant turgor loss after 9 weeks.

\begin{tabular}{lcc}
\hline & $\begin{array}{c}\text { Turgor } \\
\text { loss } \\
\text { potential } \\
(\mathrm{kPa})\end{array}$ & $\begin{array}{c}\text { Plant } \\
\text { available } \\
\text { water }\end{array}$ \\
Treatment & -25.3 & $\left.\mathrm{~cm}^{3 \cdot} \mathrm{cm}^{-3}\right)$ \\
\hline SPV:C & -32.9 & 0.46 \\
SPV:A & -29.9 & 0.48 \\
SPV:M & -31.0 & 0.47 \\
SPVC:C & -28.1 & 0.44 \\
SPVC:A & -29.3 & 0.41 \\
SPVC:M & -44.5 & 0.45 \\
CPV:C & -46.9 & 0.37 \\
CPV:A & -42.6 & 0.36 \\
CPV:M & & 0.36 \\
Mean substrate & -29.4 & \\
SPV & -29.5 & 0.47 \\
SPVC & -44.6 & 0.43 \\
CPV & & 0.36 \\
Mean polymer & -33.6 & \\
C & -36.0 & 0.42 \\
A & -33.9 & 0.42 \\
M & 6.41 & 0.43 \\
LSD (0.05) & & 0.024 \\
Probability & 0.0001 & 0.0001 \\
Substrate & 0.7024 & 0.7077 \\
Polymer & 0.6594 & \\
Substrate $\times$ polymers & & \\
\hline
\end{tabular}

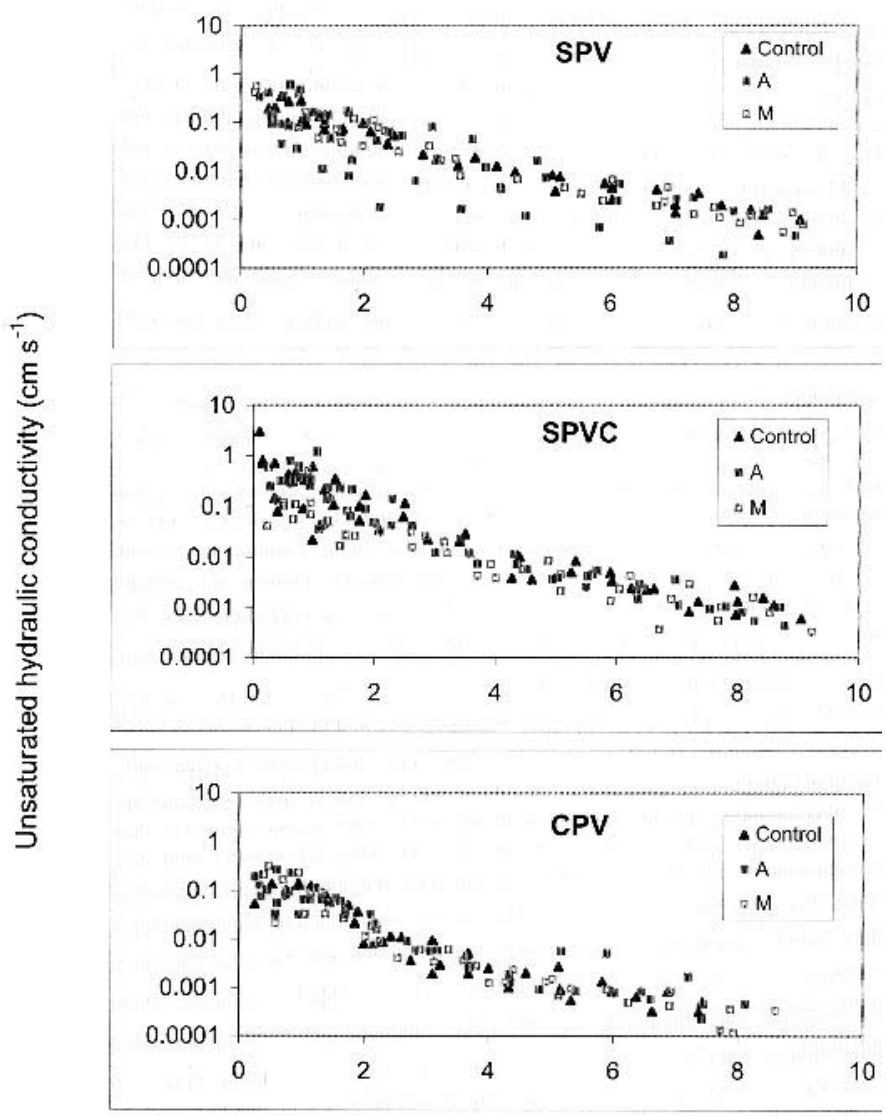

Water potential (-kPa)

Fig. 3. Unsaturated hydraulic conductivity of the different substrates with and without polymer addition. higher potentials suggests a loss of contact in peat substrate. Hydrogels might improve particle-to-particle contact, a factor believed to be limiting in water transport within peat substrate (Bernier, 1992). However, differences in unsaturated hydraulic conductivities may also be at stake, and slower transport of water may occur because of pore clogging by hydrogels (Fig. 3). Comparison of the $\mathrm{K}(\psi)$ regression parameter estimates ( $\alpha$ and $K_{S}$ ), performed replicate by replicate, using Eq. [5], indicated no significant polymer effect on $\alpha$ and a significant reduction of $\mathrm{K}_{\mathrm{s}}$ (the transformed intercepted) in the case of the SPVC medium when hydrogel $\mathrm{M}$ is added (Table 5). This last result suggests a pore clogging effect with this polymer in SPVC. The expected reduction in $K(\psi)$ at the different substrate potentials would result in lower rates of water transfer within the substrate in the drainage zone and water redistribution range of water potential (higher potential than $-10 \mathrm{kPa}$ ). Differences may also exist at potential values below $-10 \mathrm{kPa}$, but measurement accuracy was too low to go below that value. Hence, since unsaturated hydraulic conductivity could not be measured in the range of potential in which wilting occurred, the hypothesis of a better contact between substrate and roots with polymer additions can neither be supported nor rejected for potentials below $-10 \mathrm{kPa}$.

Plant analysis AND SUbSTRate Chemical Properties. Nitrogen content in biomass varied significantly with polymer addition, but was more affected by substrate composition, being higher in the SPV medium than in the other two (Table 2). Potassium concentrations in the substrate solution and in shoot tissue significantly increased with A hydrogel addition, but not with $\mathrm{M}$ addition, an expected result based on the absence of potassium in the $\mathbf{M}$ hydrogel. As some polymers may contain significant amount of potassium, potassium nutrition may be improved by displacement of potassium adsorbed onto polymer exchange sites by divalent or trivalent cations of the soil solution (Taylor and Halfacre, 1986; Dehgan et al., 1994). Potassium concentrations in shoot tissues were not affected by substrate type, but those in the soil solution were. Vermiculite contains significant amounts of potassium (Bunt, 1976), and its abundance in the CPV substrate is likely the source of this effect.

Substrate sodium content was affected only when $\mathrm{M}$ hydrogel was added to the CPV medium. The presence of sodium in the growing media is undesirable, unlike potassium. While sodium is usually not absorbed by plants (Hopkins, 1995), it accumulates along the root periphery and may increase osmotic potential at the outer root boundary, possibly reducing water fluxes into plants. However, this potentially negative effect was not important in our experiment as $\mathrm{M}$ failed to significantly reduce the growth of Surfinia in hydrogel-amended CPV substrate.

The substrate property that was significantly affected by polymer addition is $\mathrm{pH}$, with significant increases when $\mathrm{M}$ was added to $\mathrm{CPV}$, and reductions with $\mathrm{M}$ added in the other two substrates. Hydrogel A reduced $\mathrm{pH}$ in the SPV and let the $\mathrm{pH}$ of the other two substrates unaffected. According to Taylor and Halfacre (1986), a hydrogel polymer can diminish proton activity of the soil solution, stabilizing substrate $\mathrm{pH}$ during production.

WHAT FACTORS CONTROL PLANT GROWTH IN THESE SUBSTRATES? The correlation between shoot dry mass and substrate sodium content was marginally significant (Table 6), supporting the hypothesis of a possible effect that may be substrate dependent. However, while sodium appeared likely to explain the trend in dry weight reduction with M in SPVC and CPV (Table 2), it cannot explain the yield increase in SPV, and therefore remains a poor explanation for the observed effects.

The correlation between shoot dry mass and potassium tissue 
Table 5. Physical properties of substrates after 9 weeks.

\begin{tabular}{lcc}
\hline & $\begin{array}{c}\propto \\
\mathrm{K}_{\mathrm{s}} \\
\left(\mathrm{cm} \cdot \mathrm{min}^{-1}\right)\end{array}$ & $\begin{array}{c}\text { value } \\
(\mathrm{kPa})\end{array}$ \\
\hline Treatment & 0.24 & 0.66 \\
SPV:C & 0.24 & 0.75 \\
SPV:M & 0.28 & 0.69 \\
SPVC:C & 0.51 & 0.79 \\
SPVC:A & 0.58 & 0.86 \\
SPVC:M & 0.14 & 0.66 \\
CPV:C & 0.14 & 0.90 \\
CPV:A & 0.14 & 0.81 \\
CPV:M & 0.15 & 0.84 \\
Mean substrate & & \\
SPV & 0.25 & 0.70 \\
SPVC & 0.41 & 0.77 \\
CPV & 0.14 & 0.85 \\
Mean polymer & & \\
C & 0.29 & 0.78 \\
A & 0.32 & 0.81 \\
M & 0.19 & 0.73 \\
LSD (0.05) & 0.205 & 0.13 \\
Probability & & \\
Substrate & 0.0008 & 0.0759 \\
Polymer & 0.0663 & 0.4825 \\
Substrate $\times$ polymer & 0.0134 & \\
\hline
\end{tabular}

content was not significant (Table 6). While the increase in potassium may explain the yield increase in $\mathrm{A}$, it remains unlikely for $\mathrm{M}$, given the absence of changes in potassium in $\mathrm{M}$-amended substrate. Moreover, the potassium tissue content could not be considered as deficient. In such a case, any increase in potassium content can be considered as luxury consumption, with no significant expected effect on crop performance (Gardner et al., 1985; Hopkins, 1995).

$\mathrm{pH}$ did not seem to be involved either. We obtained a significant negative correlation between $\mathrm{pH}$ and dry mass within a range (between 4 and 5) where $\mathrm{pH}$ is expected to increase plant yield and for which therefore, correlation should be positive. Hence, this hypothesis appears unlikely. Salinity, however, may have been related to plant growth, as indicated by a significant negative correlation between electrical conductivity and shoot mass. Salt levels in the substrates were significantly different (Table 2 ) and may explain the effect on plant growth.

Total substrate air content was not significantly correlated to plant growth. Values of $\theta_{a}$ remained in the 0.20 to $0.30 \mathrm{~cm}^{3} \cdot \mathrm{cm}^{-3}$ range, a close to ideal value (Verdonck and Gabriëls, 1991). The correlation between the rate of loss of hydraulic conductivity $(\propto)$ and shoot dry weight was significant but low, suggesting that water transfer was not a strong driver in the observed growth differences.

Shoot dry mass was positively and strongly correlated with both PAW and AW. This supports the view that increased water storage capacity in the substrate favors shoot growth. The significant correlation with PAW in particular may be partially attributed to the excessive drying ( $-5 \mathrm{kPa}$ or lower) some baskets may have been temporarily subjected to, in spite of the watering procedure and target water potentials.

Finally, the correlation study suggests multiple effects of substrates and plant water availability, and some effects linked to mineral composition, $\mathrm{pH}$ and salt levels. Consequently, we applied stepwise regression models to account for collinearity among variables and to limit the number of variables to be included in the model. Their use did not allow the inclusion of significant factors other than PAW, suggesting so far a simple dominant effect of this factor to explain the difference observed.

Since PAW appeared as the most significant contributor, the evidence presented above suggests that the mechanisms resulting in the improvement of Surfinia growth may be very local. Water transfers in the soil did not seem involved at high potentials, but may be involved at very low potentials in the immediate root vicinity. Additionally, the contact of soil roots, not directly investigated in this study, may also have been involved. Örlander and Due (1986) showed that important resistance to water transfer is located at the soil-root interface in growing media. Roots, through exudation, can improve this contact (Greenland, 1979). Hydrogels could play

Table 6: Pearson correlation coefficient relating shoot dry weight to substrate physical and chemical properties.

\begin{tabular}{lc}
\hline & $\begin{array}{c}P \\
\text { coefficient }\end{array}$ \\
\hline Chemical property & -0.56 \\
Nitrate & -0.25 \\
Potassium & 0.65 \\
Phosphate & -0.42 \\
Calcium & -0.62 \\
Magnesium & -0.36 \\
Iron & -0.48 \\
Sodium & -0.56 \\
PH & -0.56 \\
Electrical conductivity & \\
Physical property & -0.33 \\
Air-filled porosity (0 week) & -0.32 \\
Air-filled porosity (9 weeks) & 0.51 \\
Unsaturated hydraulic conductivity (rate of decrease $\propto$ ) & 0.72 \\
Easily available water (-5 kPa, after 0 week) & 0.73 \\
Easily available water (-5 kPa, after 9 weeks) & 0.74 \\
Available water (-10 kPa, after 0 week) & 0.003 \\
Available water $(-10 \mathrm{kPa}$, after 9 weeks) & 0.73 \\
Plant easily available water (down to threshold) & 0.29 \\
Plant available water (to loss of turgor) & 0.006 \\
\hline
\end{tabular}


a role similar to exudates and improve the contact at the soil-root interface. Moreover, while HP effects were significant, they were small and remained limited in time. Modifying substrate components is apparently more efficient to increase water availability than adding acrylic-based polymers.

\section{Conclusion}

This study therefore shows a limited effect of the two tested acrylic-based HP products, most likely due to a better water storage between container capacity and the measured wilting point. The magnitude of the effect depended on the substrate. This study further demonstrates that HP addition in substrates has limited improvement possibilities relative to substrate composition. Finally, the HP effect noticed on the water desorption curves vanished within 9 weeks, indicating that there is no net benefit of hydrogel addition to plant maintenance after deployment. The results point to the importance of research into substrate properties as the privileged path to plant growth and maintenance improvement.

\section{Literature Cited}

Al-Harbi,A.R.,A.M.Al-Omran,A.A. Shalaby, and M.I. Choudhary. 1999. Efficacy of a hydrophilic polymer declines with time in greenhouse experiments. HortScience 34:223-224.

Allaire-Leung, S.E., J. Caron, I. Duchesne, and L.É. Parent. 1999. Changes in physical properties of peat substrates during plant growth. Can. J. Soil Sci. 79:137-139.

Ben-Hur, M., M. Malik, J. Letey, and U. Mingelgrin. 1992. Adsorption of polymers on clays as affected by charges and structure, polymer properties, and water quality. Soil Sci. 153:349-356.

Bernier, P.Y. 1992. Soil texture influences seedling water stress in more ways than one. Tree Planter's Notes 43:39-42.

Blodgett, A.M., D.J. Beattie, and J.W. White. 1993. Hydrophilic polymers and wetting agents affect absorption and evaporative water loss. HortScience 28:633-635.

Blodgett, A.M. and D.J. Beattie, J.W. White. 1995. Growth and shelf life of Impatiens in media amended with hydrophilic polymer and wetting agent. HortTechnology 5:38-40.

Bowman, D. and R.Y. Evans. 1991. Calcium inhibition of polyacrylamide gel hydration is partially reversible by potassium. HortScience 26:1063-1065.

Bowman, D., R.Y. Evans, and J.L. Paul. 1990. Fertilizer salts reduce hydration of polyacrylamide gels and effect physical properties of gel-amended container media. J. Amer. Soc. Hort. Sci. 115:382-386.

Bunt, A.C. 1976. Modern potting composts. Pa. State Univ. Press, Univ. Park.

Caron, J., P.Y. Bernier, I. Duchesne, and P. Tardif. 1998. Water availability in three artificial substrates during Prunus $\times$ cistena growth: Variable threshold values. J. Amer. Soc. Hort. Sci. 123:931-936.

Choudhary, M.I., A.A. Shalaby, and A.M. Al-Omran. 1995. Water holding capacity and evaporation of calcareous soils as affected by four synthetic polymers. Commun. Soil Sci. Plant Anal. 26:2205-2215.

Conseil des Productions Végétales du Québec. 1988. Méthodes d'analyse des sols, des fumiers et des tissus végétaux. Les publications du C.P.V.Q., Ste-Foy, Canada.

de Boodt, M. and O. Verdonck. 1972. The physical properties of the substrates in horticulture. Acta Hort. 26:37-44.

De Rouin. N. 1988. Étude de l'influence des propriétés physiques des substrats artificiels sur la croissance et le développement de la tomate de serre (Lycopersicon esculentum Mill. 'Vedettos'). MSc thesis. Université Laval, Sainte-Foy, Canada.

Dehgan, B., T.H. Yeager, and F.C. Almira. 1994. Photinia and Podocarpus growth response to a hydrophilic polymer-amended medium. HortScience 29:641-644.

Flannery, R.L. and W.J. Busscher. 1982. Use of a synthetic polymer in potting soils to improve water holding capacity. Commun. Soil Sci. Plant Anal. 13:103-111.

Fonteno, W.C. and T.E. Bilderback. 1993. Impact of hydrogel on physical properties of coarse-structured horticultural substrates. J. Amer. Soc. Hort. Sci. 118:217-222.

Gardner, F.P., R.B. Pearce, and R.L. Mitchell. 1985. Physiology of crop plants. Iowa State Univ. Press, Ames.

Gehring, J.M. andA.J.Lewis. 1980. Effect of hydrogel on wilting and moisture stress of bedding plants. J. Amer. Soc. Hort. Sci. 105:511-513.

Glinski, J. and J. Lipiec. 1990. Soil physical conditions and plant roots. CRC Press, Boca Raton, Fla.

Greenland, D.J. 1979. The physics and chemistry of the soil-root interface: Some comments, p. 83-98. In: R.S. Russell and J.L. Harley (eds.). The soil-root interface. Academic Press, London, England.

Heiskanen, J. 1995. Physical properties of two-component growth media based on Sphagnum peat and their implications for plant-available water and aeration. Plant Soil 172:45-54.

Helrich, K. (ed.). 1990. Official methodes of analysis of the association of official analytical chemists. Method 976.05. 15th ed. Assn. Offic. Anal. Chem., Arlington, Va.

Hillel, D., U.D. Krentos, and Y. Stylianou. 1972. Procedure and test of an internal drainage method for measuring soil hydraulic characteristics in situ. Soil Sci. 109:395-400.

Hopkins, W.G. 1995. Introduction to plant physiology. Wiley, Canada.

Hudson, D.J. 1966. Fitting segmented curves whose join points have to be estimated. J. Amer. Stat. Assn. 61:1097-1125.

Ingram, D.L. and T.H. Yeager. 1987. Effects of irrigation frequency and a water-absorbing polymer amendment on Ligustrum growth and moisture retention by a container medium. J. Environ. Hort. 5:19-21.

James, E.A. and D. Richard. 1986. The influence of iron source on the water-holding properties of potting media with water absorbing polymers. Scientia Hort. 28:201-208.

Johnson, M.S. 1984. Effect of soluble salts on water absorption by gelforming soil conditioners. J. Sci. Food Agr. 35:1063-1066.

Kozinka, V. 1992. Uptake and transport of water, p. 129-202. In: J. Kolek and V. Kozinka (eds.). Physiology of the plant root system. Kluwer Academic Publishers, London, U.K.

Lamont, G.P. and M.A. O'Connell. 1987. Shelf-life of bedding plants as influenced by potting media and hydrogels. Scientia Hort. 31:141-149.

Malik, M. and J.Letey. 1991. Adsorption of polyacrylamide and polysaccharide polymers on soil materials. Amer. J. Soil Sci. Soc. 55:380-383.

Mikkelsen, R.L. 1994. Using hydrophilic polymers to control nutrient release. Fert. Res. 38:53-59.

Milks, R.R., W.C. Fonteno, and R.A. Larson. 1989. Hydrology of horticultural substrates: 1. Mathematical models for moisture characteristics of horticultural container media. J. Amer. Soc. Hort. Sci. 114:48-52.

Örlander, G. and K. Due. 1986. Location of hydraulique resistance in the soil-plant pathway in seedlings of Pinus sylvestris grown in peat. Can. J. For. Res. 16:115-123.

Orzolek, M.D. 1993. Use of hydrophilic polymers in horticulture. HortTechnology 3:41-44.

Paquet, J.M., J. Caron, and O. Banton. 1993. In situ determination of the water desorption characteristics of peat substrates. Can. J. Soil Sci. 73: 329-339.

Parker, W.C. and S.J. Colombo. 1995. A critical re-examination of pressure-volume analysis of conifer shoots: Comparison of three procedures for generating $P V$ curves on shoots of Pinus resinosa Ait. seedlings. J. Expt. Bot. 46:1701-1709.

Richards, J.E. 1993. Chemical characterization of plant tissue, p. 115-139. In: M.R. Carter (ed.). Soil sampling and methods of analysis. Lewis Publ., Boca Raton, Fla.

Rigas, F., E. Sachini, G. Chatzoudis, and N. Kanellopoulos. 1999. Effect of a polymeric soil conditioner on the early growth of sunflowers. Can. J. Plant Sci. 79:225-231.

Rivière,L.M. 1992.Le fonctionnementhydrique du système substrat-plante en culture hors sol. Rapport interne, Ecole Nationale d'ingénieurs des travaux de l'horticulture et du paysage d'Angers, Angers, France.

Rivière, L.M., F. Lemaire, and M. Rousset. 1996. Hydrorétenteurs et 
substrats. PHM 376:43-45.

Seybold, C.A. 1994. Polyacrylamide review: soil conditioning and environmental fate. Commun. Soil Sci. Plant Anal. 25:2171-2185.

Stephens, D.B. 1996. Vadose zone hydrology. CRC Press, Boca Raton, Fla.

Taylor, K.C. and R.G. Halfacre. 1986. The effect of hydrophilic polymer on media water retention and nutrient availability to Ligustrum lucidum. HortScience 21:1159-1161.

Terry, R.E. and S.D. Nelson. 1986. Effects of polyacrylamide and irrigation method on soil physical properties. Soil Sci. 141:317-320.

Topp, G.C., J.L. Davis, and A.P. Annan. 1980. Electromagnetic determination of soil water content: Measurement in coaxial transmission lines. Water Resour. Res. 16:574-582.

Tripepi, R.R., M.W.George, R.K. Dumroese, and D.L. Wenny. 1991. Birch seedling response to irrigation frequency and a hydrophilic polymer amendment in a container medium. J. Environ. Hort. 9:119-123.

Ure, A.M. 1991. Atomic absorption and flame emission spectrometry, p. 1-62. In: K.A. Smith (ed.). Soil analysis-Modern Instrumental techniques. 2nd ed. Marcel Dekker, New York.

Verdonck, O. and R. Gabriëls. 1991. Substrates for horticultural crops, p. 3-7. In: R.P. Overrend and Jeglum J.K. (eds.). Proc. Symp. on Peat and Peatlands - Diversification and innovation. Quebec City, Canada, 6-10 Aug. 1989. Can. Soc. Peat and Peatlands, Dartmouth, N.S.

Wang, Y.T. 1989. Medium and hydrogel affect production and wilting of tropical ornamental plants. HortScience 24:941-944.

Wang, Y.T. and C.A. Boogher. 1987. Effect of a medium-incorporated hydrogel on plant growth and water use of two foliage species. J. Environ. Hort. 5:125-127.

Wang, Y.T. and L.L. Gregg. 1990. Hydrophilic polymers-their response to amendments and effect on properties of a soilless potting mix. J. Amer. Soc. Hort. Sci. 115:943-948.

White, J.W. 1965. The concept of container capacity and its application to soil moisture fertility regimes in the production of container grown crops. PhD thesis. Pa. State Univ., University Park. 